\title{
Building Condition Assessment: Lesson Learnt from Pilot Projects
}

\author{
Syamilah Yacob ${ }^{1}$, a , Azlan Shah Ali², Au-Yong Cheong Peng ${ }^{3}$ \\ ${ }^{1}$ Public Work Department \& PhD Candidate, University of Malaya, Kuala Lumpur \\ ${ }^{2}$ Department of Building Surveying, University of Malaya, Kuala Lumpur, \\ ${ }^{3}$ Department of Town Planning, University of Malaya, Kuala Lumpur
}

\begin{abstract}
Building condition assessment is growing and become more important in the context of the built environment and Asset Management in Malaysia. This paper presents the method and the use of a standard guidelines for Building Condition Assessment (BCA) as a tool to evaluate the physical condition of the building. The purpose of this paper is to understand the use of BCA in assessing building condition. The methodology was based on literature review, review contents from archive document of Public Work Department (PWD) Malaysia which is involved study on the existing methods, proposal, discussion, piloting, improvement, approval and analysis of data. A case study involved of 15 buildings with various function such as office, health clinic, quarters and learning institution involved by more than 300 numbers of building inspectors or assessors. The findings shows that the using of the standard for condition assessment, the building inspectors or assessors can provide the data and condition rating to the buildings according to the standard. The results then used to examine a level consistency of BCA in data collection and it will easily assessed and understood, and the appropriateness of BCA to different types of buildings.
\end{abstract}

\section{Introduction}

In year 2008, Public work Department of Malaysia have developed, expanded and implemented the Asset Management concept to the organization to improve the government service delivery. Integrated and comprehensive Asset Management is to ensure that the asset are in a good condition, secure, economical, and longer life cycle as well as to provide quality services to the people [1]. According to [2], the traditional view of asset management as the function of building and maintaining buildings has been broadened to include outcomes to stakeholder requirements using tools such as asset registers, monitoring the asset condition and use, prediction of deterioration, asset valuation, life cycle economic and others.

Building performance can be measured in many ways, the most common being condition. Building condition assessment is growing in the context of the built environment in Malaysia. Hence research by [3], building condition assessment has been practiced in other countries and in particular in the United States, United Kingdom and many other European countries. A building survey consists of an investigation and assessment of the construction and condition of building, which generally include the structure, fabric, finishes and grounds [4]. According to [5], the assessment of building condition is technically complex tasks, requiring knowledge, time and equipment. According to [6], building inspection is a testing examination against material or product. [7] noted

\footnotetext{
${ }^{a}$ Corresponding author: syamilah75@gmail.com
}

that the inspection is the process to assess the quality of the product or service in order to achieve a predetermined standards. In many countries the condition of a buildings is assessed and inspected on the basis of diagnosis of the extent of deterioration in the building elements [5]. He also mentioned that although there is differences in objectives, the assessment methods and development processes in the many countries are very similar.

\section{Building Condition Assessment (BCA)}

Building condition is very important to supports decision making and it is also critical to the management in achieving the service standards for maintenance. Building condition reflects the physical state of the buildings hence its performance. So the organizations, buildings and maintenance managers must have a knowledge in monitoring the condition of their buildings to prevent defects and failure of the buildings. Inefficiencies of the system of building maintenance work can give rise to defects and damage to the building. Defects and damage is a problem faced in any building regardless of age of buildings and construction type. Besides that inefficiency in handling defects or damage buildings systematically generate a variety of effects and negative impact to users and is also the owner of the building. The data of defects collected and registered during the assessment or inspection on site is crucial for maintenance decision. All building components have to contend with performance loss through ageing, use and also external causes [8]. 
In order to improve the current process of building inspection, a simplified, standardised and largely automated condition indication system has been developed by Public Work Department (PWD) to respond to the challenges in managing and maintaining the assets. BCA systems have been developed according to the requirement of Government Total Asset Management Manual [9] together with [10]. A condition assessment system is performed primarily to facilitate the ranking of all the components of the asset according to the amount of needed repair, and to produce consistent, relevant and useful information. By knowing the objective, examination would allow examiners to take advantage of a limited time during site inspection. Maintenance can only be effectively managed if the maintenance demand is properly quantified [11].

Building inspection is very important to support the goals of the Organization in providing office facilities, accommodation/high quality work in an environment that is safe, comfortable and sustainable manner. Low level of building performance can impact negatively on the organization and involves an increase in operating cost.

\section{Standardization}

Building inspection at a building which must be done in accordance with the standards set by the building inspector. An assessment of the condition of the building is the process of examining the entire building and infrastructure components, including equipment for mechanical and electrical systems, building frames, internal structure and finishes as well as building sites [7]. Component inspection criteria must be developed based on feedback the user base. User needs will produce objective assessment of the condition of the building. Building condition survey comparison with specifics based on objective assessment criteria the assessment. Synergy among all elements inspection and an assessment of the situation will form a cyclic process as a model to identify criteria for examining and improving the quality of design. Performance levels of buildings is the foundation to ensure that the criteria developed are able to achieve the objective. The structure, architecture, mechanical, electric, outdoor work, building facilities is the complete set of components for building inspection made valuation based on the maintainability, security, functionality and sustainability. The role and scope of the inspection should be understood by the examiners comprising Building Surveyors.

According to [8], the different results of various condition assessment methods are not a drawback in practice and it is important that within organization all building inspectors handle their own method the same way. The practice of condition assessment by building inspectors yields variable results due to subjective perceptions of the inspectors Surveyor variability is defined as the situation where two or more surveyors surveying the same building, arrive at very different survey decisions [12] and [13]. PWD has developed the standard Guideline Condition Assessment of building components including services in a year 2013. The guideline is a general guide to building inspectors in implementing the building inspection works and intended for creating consistency in the field of implementation of inspection and report preparation [10]. The aim of the standard is to ensure the inspection carried out by building inspectors comply with the inspection prescribed guidelines hence to provide the related and reliable rating and information about the defects assessed.

The scope of the inspection is covering all the Government's Asset which included civil and structural, mechanical system; and electrical system parts. The standard is aimed at building inspector which made up from various discpline such as building surveyors, architect, civil, mechanical and electrical engineers. Condition assessment should be carried out by trained inspector by using small equipment and related tools. Application of the standard include at the following stages:

i) Acceptance of the building for the purpose of operating and maintenance;

ii) Acceptance of the building for the purpose of asset or building registeration;

iii) Stages of operation and maintenance of the building;

iv) The initial assessment stage for the purpose of rehabilitation, renovation and upgrade;

v) The initial assessment stage for the purpose of conservation of buildings;

vi) The stage of preliminary assessment for the purposes of risk assessment and safety; and

vii) Building condition assessment level after a disaster

The standard is not limited to condition assessment only but also to the maintenance planning and priotizing maintenance work. Some processes and regulations have to be complied with by the parties involved so as to ensure the implementation of the inspection carried out in a more systematic manner.

\section{Rating Scale}

Building Condition assessment involved the screening process which is should be based on strategic management in assessing technical performance to fulfil the long term building maintenance expectations and related infrastructure. The condition rating that follows building assessment is used to objectively determine the current condition of building. A rating system that minimises subjective evaluation is repeatable and can be effectively used to predict future condition. The values of the condition indexes provide the means of comparing the condition of various components. The condition indexes scale and linguistic representation for building components is usually varies from others country whether it can derived from the numeric values or alphabets. 
According to [14], whatever condition categories are adopted, it is essential that they are clearly defined and that data collectors are well trained to ensure data consistency and reliability. A six -point scale has been taken as a basis for the standardised method [15]. The condition categories described possibly occurring defects without references to remedial work shown in Table 1. Other examples of condition scales and linguistic representation used are as shown in Table 2 and Table 3.

Table 1: Six-point scale Dutch Standard for Condition Assessment of building

\begin{tabular}{|l|l|}
\hline \multicolumn{1}{|c|}{ Condition rating } & \multicolumn{1}{c|}{$\begin{array}{c}\text { General Condition } \\
\text { Description }\end{array}$} \\
\hline $\mathbf{1}$ & Excellent \\
\hline $\mathbf{2}$ & Good \\
\hline $\mathbf{3}$ & Fair \\
\hline $\mathbf{4}$ & Poor \\
\hline $\mathbf{5}$ & Bad \\
\hline $\mathbf{6}$ & Very Bad \\
\hline
\end{tabular}

A five-point scale proved to be most effective meanwhile a three -point scale is too coarse for reliable results, while a seven-point or more scale is too fine and difficult for assessment staff to interpret consistently [11]. For [10], a five-point scale is used to represent the severity of each defect. The aggregate score is then used to produce a numerical rating from 1 to 5 , where 1 signifying optimal condition and 5 signifying critical conditions. Table 4 shown examples of condition scales and its representations as used in the standard guideline of BCA.

This condition assessment rating also links to the maintenance actions and types as shown in Table 5. Then, analysis to the defect findings links to the defect parameter for building condition and maintenance priority action level as shown in matrix analysis table in Table 6.

Table 2: Country Comparison of the Condition Rating Grade used for Building

\begin{tabular}{|c|c|c|c|c|c|}
\hline $\begin{array}{l}\text { Running } \\
\text { Body } \\
\text { (Government } \\
\text { / Private / } \\
\text { non-Profit } \\
\text { Org) }\end{array}$ & Australia & $\begin{array}{l}\text { New } \\
\text { Zealand }\end{array}$ & South Africa & $\begin{array}{l}\text { United } \\
\text { Kingdom }\end{array}$ & $\begin{array}{l}\text { United } \\
\text { States }\end{array}$ \\
\hline $\begin{array}{l}\text { Condition } \\
\text { Grade } \\
\text { (Buildings) }\end{array}$ & $\begin{array}{l}A=\text { Excellent } \\
B=\text { Good } \\
C=\text { Adequate } \\
D=\text { Poor } \\
E=\text { Inadequate }\end{array}$ & $\begin{array}{l}\text { 1=Very } \\
\text { good } \\
\text { 2=Good } \\
\text { 3=Fair } \\
\text { 4=Poor } \\
\text { 5=Very Poor }\end{array}$ & $\begin{array}{l}1=\text { Excellent } \\
2=\text { Good } \\
3=\text { Average } \\
4=\text { Poor } \\
5=\text { Very Poor }\end{array}$ & $\begin{array}{l}\mathrm{A}=\text { Good } \\
\mathrm{B}=\text { fair } \\
\mathrm{C}=\text { Average } \\
\mathrm{D}=\text { =0or } \\
\mathrm{E}=\mathrm{Bad}\end{array}$ & $\begin{array}{l}\text { 1=Very } \\
\text { Good } \\
\text { 2=Good } \\
\text { 3=Moderate } \\
\text { 4=Poor } \\
\text { 5=Very Poor }\end{array}$ \\
\hline Categories & Existing & Existing & Existing & Existing & Existing \\
\hline
\end{tabular}

Source: Institute Infrastructure Asset Management (IIAM) Manual (2006)

Table 3: Rating Scales and Representations

\begin{tabular}{cccl}
\hline Reference & Asset Type & $\begin{array}{c}\text { Condition } \\
\text { Scale }\end{array}$ & \multicolumn{1}{c}{ Linguistic Representation } \\
\hline Dfes 2003 & Buildings & A-D & $\begin{array}{l}\text { Grade A=Good, Grade B=Satisfactory, Grade C=Poor } \\
\text { Grade D=Bad }\end{array}$ \\
\hline NCES 2003b & Buildings & $1-8$ & $\begin{array}{l}\text { l=Excellent, 2=Good, 3=Adequate, 4=Fair, 5=Poor } \\
\text { 6=Non Operable, 7=Urgent Building Condition }\end{array}$
\end{tabular}

Table 4: Building Physical Condition Level

\begin{tabular}{|c|c|c|}
\hline Grade & $\begin{array}{l}\text { Inspection } \\
\text { Scale }\end{array}$ & Description \\
\hline 1 & Very Good & $\begin{array}{l}\text { - As New, No Defect, } \\
\text { Performing as intended }\end{array}$ \\
\hline 2 & Good & $\begin{array}{l}\text { - Minor defect, Good } \\
\text { condition, performing } \\
\text { as intended }\end{array}$ \\
\hline 3 & Fair & $\begin{array}{l}\text { - } \begin{array}{l}\text { Major defect, moderate } \\
\text { condition, still can } \\
\text { functioning } \\
\text { supervision }\end{array} \\
\text { with }\end{array}$ \\
\hline 4 & Poor & $\begin{array}{l}\text { - Major or minor defect, } \\
\text { critical, not functioning } \\
\text { as agreed service level }\end{array}$ \\
\hline 5 & Very Poor & $\begin{array}{l}\text { - Major or minor defect, } \\
\text { critical, not functioning } \\
\text { as agreed service level } \\
\text { - Very critical, not } \\
\text { functioning, risky to } \\
\text { safety and health }\end{array}$ \\
\hline
\end{tabular}

Source: JKR 21602-0004-13 (2013)

Table 5: Maintenance Action

\begin{tabular}{|l|c|l|}
\hline \multicolumn{1}{|c|}{ Priority } & Scale & \multicolumn{1}{|c|}{ Description } \\
\hline Normal & 1 & $\begin{array}{l}\text { No defect or damages, } \\
\text { element / component well } \\
\text { maintained }\end{array}$ \\
\hline Routine & 2 & $\begin{array}{l}\text { Minor Defects / damages, } \\
\text { Needs for monitoring, } \\
\text { repairs, replaced to prevent } \\
\text { serious defect / damages }\end{array}$ \\
\hline Repairs & 3 & $\begin{array}{l}\text { Major defects / damages, } \\
\text { needs for major repairs and } \\
\text { replacement }\end{array}$ \\
\hline Rehabilitation & 4 & $\begin{array}{l}\text { Critical / serious defects / } \\
\text { damages, needs for urgent } \\
\text { and immediate repairs }\end{array}$ \\
\hline Replacement & 5 & $\begin{array}{l}\text { Critical / serious defects / } \\
\text { damages, needs for urgent } \\
\text { replacement refer to } \\
\text { expert detail inspection / } \\
\text { Expert judgement }\end{array}$ \\
\hline
\end{tabular}

A five-point colour-coded rating system has been developed and proved to be most effective as mentioned by [11]. This will ease the method of assessment for staff or inspector to interpret consistently, making reports more user-friendly and easy to interpret, save time, comprehensive and also accessible to non-technical users to use the information. In table 7, the five-point colourcoded building rating is shown as a final result of the assessment. Score 1 to 5 with very good condition and action matrix to be taken is preventive maintenance, 6 to 10 , good condition with condition based maintenance, fair condition with score from 11 to 15 required for repairs work. Meanwhile rehabilitation work need for poor condition with range scores from 16 to 20 . Score 
from 21 to 25 is very poor condition and needs for replacement work.

Table 6: Matrix Analysis - score defect parameter for building condition and maintenance action

\begin{tabular}{|c|c|c|c|c|c|c|}
\hline \multirow{2}{*}{\multicolumn{2}{|c|}{ Scale }} & \multicolumn{5}{|c|}{ Maintenance Priority Action } \\
\hline & & \multirow{2}{*}{$\frac{\mathrm{E}(5)}{25}$} & \multirow{2}{*}{$\frac{\mathrm{S} 4}{20}$} & \multirow{2}{*}{$\frac{\text { SM 3 }}{15}$} & \multirow{2}{*}{$\begin{array}{l}\mathrm{R} 2 \\
10\end{array}$} & \multirow{2}{*}{$\frac{\mathrm{N} 1}{5}$} \\
\hline \multirow{5}{*}{ 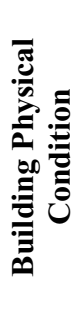 } & 5 & & & & & \\
\hline & 4 & 20 & 16 & 12 & 8 & 4 \\
\hline & 3 & 15 & 12 & 9 & 6 & 3 \\
\hline & 2 & 10 & 8 & 6 & 4 & 2 \\
\hline & 1 & 5 & 4 & 3 & 2 & 1 \\
\hline
\end{tabular}

Source: JKR 21602-0004-13 (2013)

Table 7: Building Rating and Maintenance Action

\begin{tabular}{|c|l|l|l|}
\hline Rating & $\begin{array}{c}\text { Physical } \\
\text { Condition }\end{array}$ & Action Matrix & \multicolumn{1}{|c|}{ Score } \\
\hline A & Very Good & $\begin{array}{l}\text { Preventive } \\
\text { Maintenance }\end{array}$ & 1 to 5 \\
\hline B & Good & $\begin{array}{l}\text { Condition Based } \\
\text { Maintenance }\end{array}$ & 6 to 10 \\
\hline C & Fair & Repairs & 11 to 15 \\
\hline D & Poor & Rehabilitation & 16 to 20 \\
\hline E & Very Poor & Replacement & 21 to 25 \\
\hline
\end{tabular}

\section{Methodology}

The approach of the research is quantitative research which is well-suited for the study to testing the understanding of the BCA. The study also based on literature, analysis content from BCA reports by PWD. The objectives of the study is to examine the level of consistency data collection and it will easily access and understood. The study on the existing methods such as Building Condition Maintenance Assessment System (BCMAS) 2010 were analyzed. The purpose of the BCMAS method are to for expedite maintenance works, ensure proper financial management, assisted in planning and monitoring. According to supporting data (BCMAS report, 2010), the method were not accurate enough and not achieved the objectives. The development of the new standard is based on the requirements towards National Assets Management. International rating comparison, namely Australia, New Zealand, South Africa, United Kingdom and the United States are reviewed for reasonableness of the use of this identification of BCA in Malaysia. The results of the BCA are a more systematic approach in building maintenance practices.

A case study involved of 15 buildings with various function such as office, health clinic, quarters and learning institution at certain state in Malaysia. The content of 23 numbers existing BCA reports were studied to ensure that the workable of the standard developed and to attain the consistently in the rating result by different assessors. And it also to ensure the suitability the used of the standard to the various function or categories of buildings with different sizes of floor area. The case study was carried to find out if the instruction in the manual clearly explained, easy to follow, understand and correctly assessed by assessors. The case study helped the organisation for building inspection and improvement for the standard especially to the inspection process. Besides that, the case study also helped to provide maintenance data and other relevant information regarding to the condition assessment. The inspections were performed by 307 assessors consisted multilevel of skill through training course to make sure the reliability and validity scores of the rating given and the use of standard procedure. The findings from the study were analysed and delivered to the conclusions.

Condition of buildings will be assessed and collected through Building Condition Assessment (BCA) standard. Inspection method performed is based on the visual inspection by using appropriate tools. The assessment mainly from physical site visit. Inspections done subject to the scope of limitations [16]. This is the initial screening examination for the purpose of evaluating the condition of the assets by Building Surveyors. The result analysis of inspection shall refer to experts for follow-up action. Figure 1 shows the condition assessment process according to the guideline. Building inspectors should carry out an initial review examination as one needs to examine the detailed investigation by engineers. However it depends on the type and level of disability and damage reported in the initial visual inspection report.

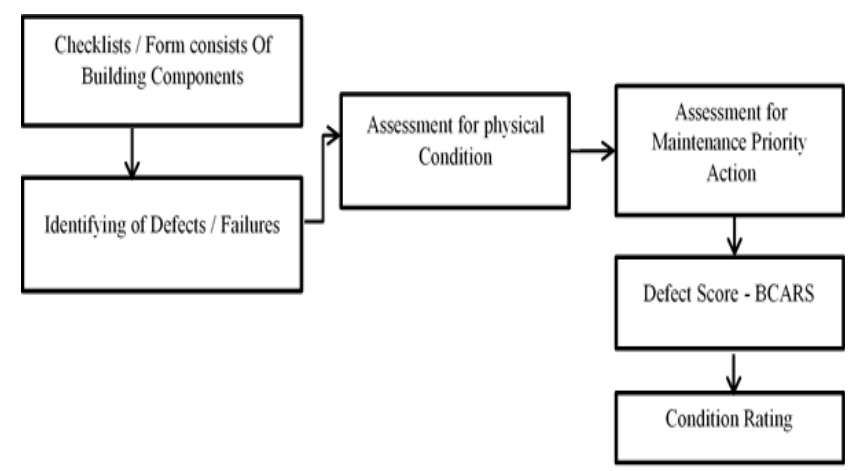

Source: Source: JKR 21602-0004-13 (2013)

Figure 1: Condition Assessment Process

A checklist was used according to the standard for registering the information of the building, identification, characterisation, defects in functional element, evaluation of condition of defect, and maintenance action. Asset condition checklist was developed to know the status of the output and as input of the operation and maintenance of the building, as initial inspection report for building condition and also to make a recommendations to the 
experts for follow-up action. The data collected in the checklist was compiled for registering the information of the defects. The checklist was divided into five (5) parts which is building informations forms, civil and structure, mechanical, electrical and external work forms.

The assessing of defect must come for the first step by identifying the type of defects. This statement was supported by [8], the assessing of defects occurs first and without the information one could not formulate maintenance activities and estimate the costs. The intensity of the defects will influences building component or element to function properly. The extent of defects strongly influences the condition of the building components and lead to the condition rating [8]. The assessment of defects assessed by comparing the current condition or performance with the original state of conditions. The condition of the buildings are assessed and summarized in the preparation of reports based on the following criteria such as functionality, security, maintainability and sustainability. The defects is assessed on five-point scale: grade 1 with no defects (very good), grade 2 with minor defects (good), Grade 3 with major defects (fair), Grade 4 with Major or minor defect, critical, not functioning as agreed service level (Poor) and Grade 5 consists of grade 4 and very critical, not functioning, risky to safety and health (very poor). All the findings identified are assessed and recorded in building condition schedule and in defects sheets. The defects were illustrated with photographs. The details inspection of the defects to be filled and checked on readiness condition damage or defects found and priority defects or damage needs to be given priority.

The physical condition assessment have to link with maintenance priority action to be taken prior defects findings. The maintenance actions taken will based to priority with scale 1 with no defects (Normal), scale 2 with minor defects (routine), scale 3 with major defects (repairs), scale 4 with critical or serious defects or damages, needs for urgent and immediate repairs (rehabilitation) and scale 5 with critical or serious defects or damages, needs for urgent replacement, refer to expert detail inspection or expert judgement (replacement). According to (Abbott, Mc Duling, Dr, \& Schoeman, 2007) the condition assessment rating is linked to the related maintenance actions and types due to the different portions of component could be different conditions and it required the range of maintenance actions.

The extent of defect and the maintenance action combined in a defect score which is Building Condition Assessment Rating System (BCARS). The analysed data of the defect are summarised and a major defective elements were identified and data were sorted for the rating and for analysis. The score obtained from the building condition schedule determine level of defects finding such as very good, good, fair, poor and very poor. The overall building rating derived from the total mark from sum up matrix analysis divided by total number of defects. This is the same method of calculation research by [17] a rating system that minimises subjective evaluation is repeatable and can be effectively used to predict future condition.

\section{Findings and Analysis}

The implementation of the standard BCA officially was in 2013. The development of the method started in a year 2011. Since that the implementation of method started in 2011 for the improvement and enhancement of the method developed. The execution of the BCA involved the total numbers of 15 types of building with various scale of categories of buildings. It involved the total 23 numbers of building inspection reports which is 11 numbers for office buildings and others for canteen, hanger, quarters, stadium, hostels and health clinics. The inspection was performed by 307 numbers of building inspectors including 4 numbers of trainers. It also involved the total of 196,584 square meters floor area. Table 8 show the list of buildings and finding on time taken to the complete assessment on site.

Through the observation of the findings, the time taken to complete the inspection is between 1 to 4 days and it is dependent to the numbers of the assessors. Figure 2 shows that the percentage of total building according to the time taken to carried out the inspections. It shows that $20 \%$ or 3 buildings completed inspected in 1 days. $60 \%$ in 2 days, $13 \%$ completed in 3 days and $7 \%$ completed in 4 days. This situation strongly shows it is possible to complete the inspection within 1 to 3 days.

Table 8: List of projects and findings for office buildings

\begin{tabular}{|c|c|c|c|c|c|c|}
\hline$\dot{0}$ & $\stackrel{\stackrel{\infty}{\Xi}}{\stackrel{0}{\Xi}}$ & $\stackrel{0}{\stackrel{0}{2}}$ & $\stackrel{\Xi}{\stackrel{\Xi}{Z}}$ & 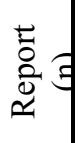 & 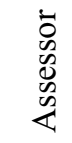 & $\stackrel{\Xi}{\Xi}$ \\
\hline 1 & $\mathrm{~A}$ & Office & $14,400.00$ & 1 & 4 & 3 \\
\hline 2 & B & Office & $1,200.00$ & 1 & 10 & 2 \\
\hline 3 & $\mathrm{C}$ & Office & $14,136.00$ & 1 & 50 & 2 \\
\hline 4 & $\mathrm{D}$ & Office & $9,958.00$ & 1 & 13 & 2 \\
\hline 5 & $\mathrm{E}$ & Office & $9,958.00$ & 1 & 13 & 2 \\
\hline 6 & $\mathrm{~F}$ & Office & $2,476.00$ & 1 & 24 & 2 \\
\hline 7 & $\mathrm{G}$ & Office & $6,715.00$ & 1 & 20 & 2 \\
\hline 8 & $\mathrm{H}$ & Office & $7,577.00$ & 1 & 7 & 1 \\
\hline 9 & I & Office & $1,054.00$ & 1 & 104 & 1 \\
\hline 10 & $\mathrm{~J}$ & Office & $7,527.00$ & 1 & 4 & 1 \\
\hline 11 & $\mathrm{~K}$ & Office & $20,260.00$ & 1 & 10 & 2 \\
\hline 12 & A & Canteen & 360.00 & 1 & 4 & 3 \\
\hline 13 & B & Hanger & $19,502.00$ & 1 & 10 & 2 \\
\hline 14 & $\mathrm{~F}$ & Hostel & $5,224.00$ & 1 & 24 & 2 \\
\hline 15 & L & Stadium & $19,517.00$ & 1 & 9 & 2 \\
\hline 16 & M & Stadium & $28,000.00$ & 1 & 15 & 2 \\
\hline 17 & $\mathrm{~N}$ & Quarters & $8,058.00$ & 1 & 11 & 3 \\
\hline 18 & $\mathrm{O}$ & Clinic & $20,662.00$ & 6 & 4 & 4 \\
\hline
\end{tabular}




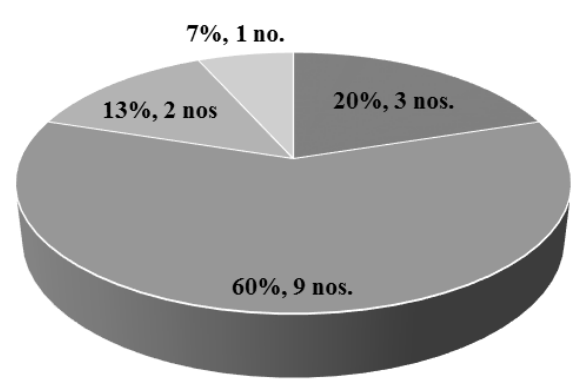

Days

Figure 2 Percentages of total buildings according to the days.

According to figure 3, the detailed inspection took average 3 days to complete the inspection. And this have proved that the time taken to complete the inspections between 1 to 3 days depend on floor area and also the number of the assessors. The number of assessors also important to influence the time taken to complete the inspection although to the various types of buildings with different floor area. Meanwhile according to figure 4, the analysis shows that there is relationship between floor area assessed and the number of assessor in determining the time to complete the inspections. A common form of linear equation is used to floor area, assessor as variable against time of inspection. Variables is independent and it is proved that the possible time of inspection is within 2 days for average 7,000 square meters floor area inspect by only 2 assessors.

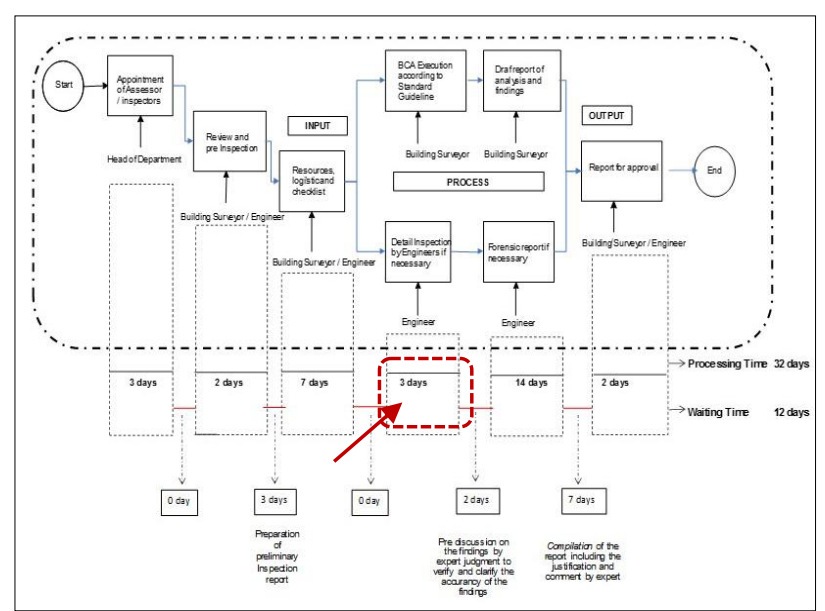

Source: JKR 21602-0004-13

Figure 3 shows the average time taken to complete the assessment including report preparation.

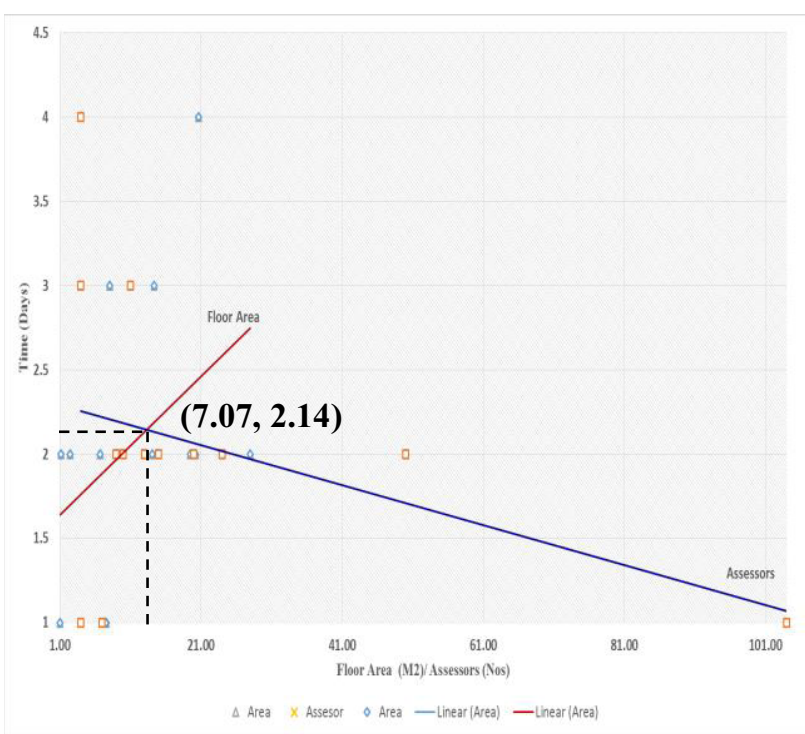

Figure 4 Relationship between floor area, assessor and time

\section{Discussion and Conclusion}

From the analysis it is can conclude that, by using the BCA standard, the rating of the buildings achieved the same result and reliable to produce accurate rating for planned maintenance work and budgets. Meanwhile the time of inspection will be defer and more shorten when more assessors used to inspect the buildings. However to assess the building defects or building condition is not quite easy to learn from books, guidelines or standard without proper training and also from the experiences in assessing the building condition. The level of understanding of assessor can affect the time taken to complete the inspection. Currently, the intensity of the defects is depends on acceptance or judgment of the assessor or building inspector. Therefore, more experiences gain by the inspector, more accurate the data and also the judgement give to the intensity of the defects. Building inspector requires skill to identify defects and familiar with reporting procedures to ensure the consistency and appropriateness of BCA to different types of buildings.

\section{Acknowledgement}

This work was carried out and supported by Building Maintenance and Facility Branch, Public Work Department (PWD) Malaysia which was supported the VACCINE Program - The Implementation of Building Condition Assessment (BCA) as a Performance Tool and to Enhance Maintenance Management Process. The warmest thanks also go to PWD Head Quarters Mechanical Engineer Branch, Electrical Engineer Branch, Forensic Department, Building Department, PWD Selangor, Melaka, Kelantan, Kedah, Perak, Wilayah Persekutuan Sabah, INTAN, PTPTN and UiTM Perak. 


\section{References}

1. PWD. Dasar Pengurusan Aset Kerajaan. Kuala Lumpur (2009)

2. Mihai, F., Binning, N., \& Dowling, L. A Framework for Assessing Asset Management Performance In Australia. Australia: Main Roads Western Australia.(2002)

3. (INGENIUM), A. o. (2006). International Infrastructure Management Manual. New Zealand: Institute of Public Works Engineering of Australia.(2006)

4. (CIC), C. I. (1996). Definitions of Inspections and Surveys of Buildings. London: CIC.(1996)

5. Joao Antonio Costa Branco Oliveira Pedro, J. A. Portuguese method for building condition assessment. Journal of Structural Survey, 25(34), 322-335 (2008)

6. Ramly, A. Panduan Kerja-kerja Pemeriksaan Kecacatan Bangunan. Malaysia: Hizi Print Sdn. Bhd.(2006)

7. Wordsworth, P. Lee's building Maintenance Management, 4th edition. Oxford Blackwell Science Ltd.(2001)

8. Straub, A. Dutch Standard for Condition Assessment of Buildings. Journal of Structural Survey, 27(1), 23335.(2009)

9. PWD. Manual Pengurusan Aset Kerajaan (MPAM). Kuala Lumpur, Malaysia: Public work Department.(2009)

10. PWD. Building Condition Inspection for Existing Building.Kuala Lumpur, Malaysia: Public Work Department.(2013)

11. Abbott, G. R., Mc Duling, J. J., Dr, P. S., \& Schoeman, J. C. Building Condition Assessment: A Performance evaluation tool towards sustainable asset management. CIB World Building Congress, 649662.(2007)

12. Kempton, J., Alani, A., \& Chapman, K. (2001). Surveyor variability in educational stock survey-a lens model study. Journal of Facilities, 20(5/6), 190197.(2001)

13. Kempton, J., Nichol, S., Anumba, C., \& Dicken, J. Surveyor variability in large-scale house condition survey. Journal of Structural Survey, 19(4), 156162.(2002)

14. Pitt, T. J. Data Requirements for the prioritization of predictive building maintenance. Journal of Facilities, 15(3/4), 97-104.(1997)

15. NEN, 2. Condition Assessment of Building and Installation Components. Dutch: NEN. (2006)

16. Kleiner, Y. Scheduling Inspection and Renewal of Large Infrastructure Asset. Journal of Infrastructure Systems, 7(4), 136-143.(2001)

17. Hamzah, N., Mahli, M., Che Ani, A. I., Tahir, M., Abdullah, N., \& Tawil, N. The Development of Smart School Condition Assessment Based on Condition Survey Protocol (CSP) 1 Matrix: A Literature Review. Science, Engineering and Technology, 620625.(2010) 